\title{
Study on Cultivation Strategy of Customer Loyalty Based on Internet Marketing
}

\author{
Zhen Cuimin \\ Economics School, \\ Hebei United University \\ Tangshan, China
}

\author{
Bian Shehui \\ Qian'an College, \\ Hebei United University \\ Tangshan, China
}

\begin{abstract}
In internet marketing environment, many businesses have gradually realized that gaining and maintaining customer loyalty is important source of long-term profits. This article firstly elaborates the connotation and importance of customer loyalty in internet marketing environment, then analysis the main factors on the formation of customer loyalty and proposes the strategy of raising the customer loyalty. Finally, the conclusion is given that the customer loyalty doesn't only wins with the technology, but also needs enterprise improve its product and the service progressively and establish the link with customer's emotion by the sincere manner and consummation service.
\end{abstract}

\section{Key words-Internet marketing, Customer loyalty, Strategy}

\section{INTRODUCTION}

Along with the internet and electronic commerce vigorous development, people's shopping behavior extends gradually from the traditional entity store to the electronic store. Up to December 31, 2011, the Chinese web c am scale ach ieves 513,000,000 people; network shopping user scale achieves 214 million. The rapid development of online shopping, the dramatic increase in the number of online stores and customers can fully compare the products and s ervices businesses at least time and energy, which have cau sed the network market steep competition and th e customer loyal establishes and maintains with difficulty. How to gain the customer loyalty in internet marketing environment has become the network operators to concern about. However, in the academic, the research on the customer loyalty in internet marketing environment is more from the United States and other developed countries in e-commerce, whether its concept and theory can be transplanted to our country still waited for examining. In th e customer loyalty's formation mechanism and cultivation aspect, empirical studies of domestic science are rare, many research are on ly based on experience summary in preliminary examination and the perceptual judgment. The val ue degree which should receive w ith the network customer loyalty is very asymmetrical.

\section{THE IMPORTANCE OF CUSTOMER LOYALTY IN INTERNET MARKETING ENVIRONMENT}

Customer loyalty in internet marketing environment is also called electron loyalty, E-loyalty. It is online customer who approvals and faiths the electronic commerce enterprise product and service, then visits enterprise's website repeatedly, purchases enterprise's product and th e service repeatedly, increases and enhances the business interest or image consciously. In other words, E-loyalty is online customer trusts highly and loyally to the enterprise in the behavior, psychology and emotion.

Regardless of being the entity environment or the virtual environment, the cultivation and maintenance customer loyalty is critical path of enterprise profit. Improving E-loyalty has the following important aspects.

\section{A Revenue growths continuously}

The loyal custo mer will be not only choose to purchase this enterprise's product or service redundantly, but also may produce "the overflow effect" to this enterprise. The loyal customers will not only continue to $\mathrm{p}$ urchase the origi nal commodity, but also i ncrease commodity type in this enterprise, thus could increase this enterprise's business income greatly.

\section{B Marketing costs decrease continuously}

It usually needs many advertising costs to devel op a new customer, but the loyal cu stomer nearly does not need the propaganda to let the $\mathrm{m}$ purchase this electroni $\mathrm{c}$ commerce enterprise's product or service. The loyal customer, who transacts routinely and familiar with enterprise's product and the flow, will save enterprise's service cost. Thus it would reduce enterprise's marketing expense unceasingly.

\section{Enterprise image sets up continuously}

The loyal customer can become this electronic commerce enterprise "the missionary", they will always strive to promote and recommend enterprise products and services to the periphery person, and even they are willing to accept products or services which they should pay a higher price. Along with network advertisement increase sharply, when the people are difficult to distinguish facing genuine and fake advertisement, they are more attention to the recommendation of friends and family at the time of their purchase decision. Thus enterprise's popularity and brand reputation naturally are raised.

\section{Enterprises' market position consolidates continuously}

When the customer has produced loyally to some electronic commerce enterprise, it wi ll basically stop the behavior of searching the related brand information, refuse to buy the business competitor's products or services, and provide valuable information to the enterprise, thus this enterprise's position in th e competitive market has 
consolidated.

\section{E Enterprise develops long-term and stability}

When the elec tronic commerce enterprise has a stable of loyal customers, its revenue will increase unceasingly, moreover the marketing expense th at has been saved down will be used to improve the product and service to attract more loyal customers, and the huge loyal customer group may save more costs for the enterprise. Such virtuous cycle gets down, it may cause the enterprise develops long-term and stability.

\section{FACTORS ON AFFECTING THE FORMATION OF} CUSTOMER LOYALTY IN INTERNET MARKETING ENVIRONMENT

Through the related research, it divides the factors into the direct drive factor, the intermediary factor and the adjustment factor according to function way of the formation of customer loyalty. The direct drive factor includes product quality, service quality, website design, enterprise image. The intermediary factor includes network customer satisfaction and network custo mer trust, the adjustment factor includes customer personal characteristics and the $\mathrm{n}$ etwork environment, as shown in fig. 1.

\section{A Product quality}

Product quality is the basis for the formation of customer loyalty, the customer who only obtains satisfaction of the product may have the $p$ ossibility to form the desire of redundant purchase. Product quality includes product price, product brand, product multiplicity, the degree of product customization and so on. And the reliable quality is customer's essential requirement to the products; the same quality level of the lower prices is the fundamental driving force of customer loyalty. At the same time, when customers purchase products or ser vices, they ho pe to gain more practical interests by the smaller cost and pursue the product or service personalization and diversification.

\section{B Service quality}

The quality product and the reasonable price no doubt will affect the customer decision-making, these two variables can easily imitated and duplicated by the competitor, but the high quality of service is difficult to replicate. The high quality of service is the network customer's first choice especially when the internet is popular; Quality of service can be divided into pre-sale, sells, post-sale service quality, the enterprise should not only provide good sells service, also should pay attention to pre-sale and post-sale service.

\section{Web site design}

In the "ey eball economy" era, it is crucial for traditional enterprise or e-commerce enterprise to arouse the attention of customers at the first time. First, the website design style is the visitor's first impression of the enterprise; it should be adapted to the subject. Next, rich website information and content; A rich, reasonable layout, clear theme of the site is more easily to cause the customer "to settle down" than the website whose interface is complex and difficult to navigate. Thirdly, speed and convenience is b asic security to ensure people who pursuits of fast-paced life continue to patronize in electronic commerce time. The website should provide the quick search eng ine and page operation, the stability of website back-office support and ser ver, because they can affect customer shopping process, thu s affect the customer satisfaction.

\section{Enterprise image}

In electronic commerce domain, Customer's cognition to enterprise image will significantly affect the trust between the site and custo mer. Facing the vast amounts of commodity information, the majority customers will choose a g ood reputation, well-known, strong customer identification store, such as imperial crown store and high product appraisal store. Because the good enterprise image is h elpful in reducing customers purchase risk, e nhancing purchase confidence, simultaneously it can satisfy the customer to obtain the society and the psycholo gical demand outside the product function, thus would affect their preferences choices and estab lish loyalty to the enterprise.

\section{E Customer personal characteristics}

Personal characteristics of customer is one of the factors affecting customer loyalty. It includes the customer's values, the attitude toward consumption, the inc ome, the education level, the degree of network involvement and so on . Online customers have different habits of technologies and service requirements, price sensit ivity and brand $\mathrm{p}$ references. Loyal customers often contact some specific website which is recommended by friends. The customers who fling between the homepage are generally price-sensitive or like to in quire discounting news.

\section{F Network environment}

Network environment includes the qu ality of network connections, the speed of logistics, the security of online transactions, internet trading market discipline, completeness of the laws and regulations, atmosphere of network credit and so on. These factors may not be cau sed and controlled by some on-line store. But once network customer hasn't had the happy feeling to its purchase process because of network environment, it will affect purchases of entire E-store's goods.

\section{STRATEGIES ON CULTURING CUSTOMER LOYALTY IN INTERNET MARKETING ENVIRONMENT}

\section{A Enhance network customer's degree of satisfaction}

More and more network enterprises have already realized that improving customer satisfaction is the foundation for establishing customer loyalty. Specifically, there are following ways to enhance the internet customer satisfaction.

1) Completes the entire process service for the customer

Establishing and maintaining the network customer's loyalty must provide the transaction of entire process service. The complete customer service system includes: implementation and engag ement of pre-sale, sells, the post-sale service. The website should guarantee that the website and customer's information communicates channel be unimpeded, understand the customer's demand accurately and quickly, and provide customers with customized services during pre-sale service; the website should provide quickly, conveniently, comfortable communication for the customer, 
provide customer the more convenient payment ways, provide customer the allocation service according to customer needs and product features during sells service; The website must be able to consider the questions that customer will possibly meet after product has been sold, and provide customers with feasible and satisfactory solution aims at these qu estions during post-sale service.

2) Sets up the good enterprise image

It is the prerequisite by setting up the go od enterprise image for the maintenance of E-Loyalty. First, the enterprise should ensure that commodity provided be qua lity, consistency, timeliness. The quality means the qu ality of commodity must good; consistency is the online description of the goods and the actual provision of goods should be consistent; Timeliness is the speed of delivery should be in time. Second, the network enterprise's domain name must be bright and succinct. As the network enterprise, it is a positive way to attract customers to let them familiar with own domain name to find own website easily in the Internet. Finally, promote enterprise's prestige. The net work marketing is not the direct money exchange; customers are not easily using this trading method if enterprises do $\mathrm{n}$ ot have a very good reputation. Therefore, enterprises should treat eve ry customer's assessment and recommendations on the business correctly.

\section{3) Implements the personalized network marketing}

In personalized demand time, the enterprise must seize opportunities to $\mathrm{p}$ rovide personalized goods and service. Enterprises can use the following two for $m s$ to $p$ rovide personalized service. Firstly, enterprise site recommends personalized service. According to th eir database records of customer information and intelligent software, enterprise site infers customers need and preferences in order to provide different customers for different services. Secondly, customers help personalized service themselves. According to $t$ heir preferences, customers select the service or the service combination provided by the website freely. The enterprise should respect the uniqueness of customer and let the customer lead own expense experience and feeling.

\section{B Enhance network customer's trust}

Trust is a prerequisite for customer loyalty; the enterprise which only considers truly for the customer benefit and reduces customer's sensation risk can obtain customer trust and win customer loyalty really. Trust from many aspects, such as product or service quality, reasonable price. But on-line, the very important factor also has: protect customer's on-line safety, fulfill the co ntract timely and accurately, prevent fraud transactions and so on. Therefore, enterprises must ensure the quality of products sold and service quality, this is the most basic con ditions for building confidence. Secondly, it must ensure the security of transaction process, customer registration information and onl ine chatting data. The network enterprise must invest sufficient human and material resources and strengthen the hardware and software's construction to ensure the security of online transactions and the confidentiality of personal information. More, the network enterprise should fulfill the contract accurately and promptly. For the network enterprise, del ivery the customer specified products to designated locations timely must unify its on-line service and net's delivery service system.

\section{Establish complete customer information system}

The different customers have different requirements on the website, customer value, E-trust and so o n. If the enterprise attempts to cater to all customers' demand, this will result in great difficulties to the website marketing work. Therefore, first of all, the enterprises should establish the customer file accordance with the customer's individual characteristics, network experience, the purchase behavior and so on . Carry on the classification to the customer according to the customer file. Identify the customers who are the most profitable and most worth preserving from numerous customers, and take them as the marketing goal to establish customer information system; Secondly, the enterprises shoul d improve the customer information system in view of the goal customer. Through the customer information system's establishment and consummation, the enterpri se can understand customer's demand fully and provide a better service for the customer. Meanwhile, the data in the customer information system is the important basis on the personalized marketing and customer relationship management. In short, through good management of customer information system, the enterprise can in crease the old loyal customer's quantity, add the new loyal customer's quantity, and strengthen customer communication and implementation of network marketing.

\section{Improve the entire network environment continually}

The environmental factor is an important restriction factor on increasing customer confidence. If the entire network consumer environment has the remarkable improvement, it will be adv antageous in promoting customer's network trust. To have a good network environment, firstly, we must have a security, reliable communication network to ensure transaction information delivery safely and promptly. The electronic commerce website can establish the correspondence trust through the investment of infrastructure construction as soon as possible. Secondly, the government should take some measures to enhance the security of online shopping by establishing and improving the relevant legal system, by improving the relevant restraint mechanism, by establishing the authority of the enterprise credit evaluation system, by raising the entire social truth standard and so on. Thirdly, e-commerce enterprises must abide by credit and gain the trust of customers. Enterprises s hould ensure the provided commodity high quality, timeliness, consistency. Strengthen the cooperation with logistics companies, guarantee database server absolute safety to prevent hackers from intruding the network to steal the information, and guarantee customer's individual privacy is not public to the third party before its agreement in order to create the network credit atmosphere.

\section{CONCLUSIONS}

In today's era of network marketing, the electronic commerce enterprise who wants to maintain the competitive edge in the co mplex global competition must take the customer as the center, cultivate and retain loyal customers. Loyal customer is not only the important determinant factor of company's competitiveness, but also is an important source of 
corporate long-term profits, and is the enterprise's foundation of survival. The network marketing time's customer loyal doesn't only win with the technology purely, but also requires enterprises to improve their products and services continuously, needs enterprises to build emotional connections with customers by the sincere attitude and perfect service.

\section{REFERENCES}

[1] Wu Shijun: The Analysis on Factors Influencing the Network of Loyalty [J]. Business Economics, $2009: 82 \sim 84$

[2] Yan-Yang Liu, Zheng Yu: E-Time Customer Loyalty Analysis and
Strategy [J]. Theory and Methods, 2007:31 35

[3] Bao Jinlong: The Empirical Analysis on Factors Influencing the B2C Website Customer Loyal [J]. East China Management of Economy, 2007:131 135

[4] Liu Mei: The Empirical Analysis on Fac tors Influencing the B2C E-Retail Website Customer Loyal [D]. Zhejiang University of Commerce and Industry, 2007

[5] The growth scale of network shopping user., 2012.8.13, http://b2b.toocle.com/detail--6052304.html. 